\title{
The Influence Of Extrinsic Motivation On Students' Retention And Study Success
}

\author{
Nur Hidayah Mohamed Yunus, Aini Nazura Paimin
}

\begin{abstract}
There are concerns over the growing need of more engineers to work for the market. However, graduation rate in this field has decreased over the years. There is an urge to understand why some engineering students can achieve success while others not. Extrinsic motivation is seen as an important motivational factor that could influence students' decision to complete or quit their studies in engineering courses. The current study explores extrinsic motivation of engineering students using a qualitative approach. Data were collected using semi-structured interviews, where 24 final year engineering undergraduates from the Malaysian Technical University Network (MTUN) universities were selected using referral and chain referral techniques of sampling. Data were analysed using a thematic coding approach and Atlas.Ti software was used to assist the coding process. The findings found that the successful students were mostly influenced by three main extrinsic factors namely people, program, and incentives.
\end{abstract}

Index Terms: External motivation, retention, success, higher education

\section{INTRODUCTION}

Education plays a key role in economic development and development of a country (Moulod, Chua, Ahmad, Leong, \& Alias, 2016). One measure of progress in a country is its economy, while economy in general is measured by the performance of the industry. This necessitates a country to foresee and prepare quality man powers to meet the industry's needs. Ashar (2016), states that the engineering field is one of the key areas that are closely linked to a country's development. The same study he also pointed out that Malaysia in dire need of qualified engineers by 2020. The sixth challenge of the Vision 2020 shows the government's commitment in building a technologicallyadvanced nation.

The relationship between engineering knowledge and human capital is important in a progressive nation. This is because having knowledgeable and highly skilled human capital is the prerequisite for the efforts of becoming a developed country with people of high income. To achieve this goal, it requires at least 200,000 engineers to serve in the Malaysian industry (Lashari, 2015). The Malaysian authorities have executed many plans targeting at empowering future engineers through increasing the number of student enrolment into engineering degree programs in higher education institutions. However, a high rate of

Revised Manuscript Received on April 19, 2019.

Nur Hidayah Mohamed Yunus, postgraduate (masters), Universiti Tun Hussien Onn Malaysia, Johor, Malaysia

Aini Nazura Paimin, lecturer, Universiti Tun Hussein Onn Malaysia, Johor, Malaysia enrolment does not guarantee a high return in terms of number of successful engineering graduates. The cases where students reading bachelor of engineering are giving up early during their studies have become a polemic among our universities.

The number of highly-skilled workers in this country is lower compared to their counterparts. The low to moderately-skilled workers are dominating the workforce in our industry based on recent data in 2016. The country needs more highly-skilled manpowers to bulid this nation based on technology (Lashari, 2015). Hence, providing qualified engineers through education is a critical issue. Employers' needs could not be satisfied if there are still students drop out in the first place. Based on the statistics of student enrolment for the engineering programs by the Ministry of Higher Education Malaysia (2016), the number of students enrolling in Bachelor's degree in engineering studies is higher than the number of students graduating in the consequent years. This shows that some students failed and did not finish their studies within the specified period. The number of drop-outs in the field of engineering is still inconclusive. However, we have a clue that the number of students who quit or defer their engineering studies in between 15 to 30 percent each year.

Much effort has been put in attracting young people to make engineering as their choice of specialisation. However, this effort is in vain without ensuring that the engineering students retain in their programmes until graduation. Therefore, it is important to understand factor of student retention and most importantly their success in engineering studies.

\section{LITERATURE}

Review of past studies on factors influences success in engineering have shown that there are several that effect student retention in engineering programs. This paper focuses on only the external factors such as environment, study facilities, friends and family. These factors will be discussed further in this section.

\section{A. Study Success and Retention}

Gaining admission to a higher education institution is one 
thing, achieving academic success in a program of study is another thing. An issue of concern in higher education institutions across the world is the retention and success of students in their studies. This has been a study of interest among researchers in Engineering Education (Zanden et al., 2018). Eventhough much research have been conducted in this area, the high attrition rate reflects that factors influencing students success has not been fully understood. Therefore, it is important to gain a better understanding of study success in higher education. Meens (2018) defined study success as academic achievement. Similarly, according to York, Gibson, and Rankin (2015), academic achievement is an outcome that captures the quality of students' academic work such as course grades or GPA.

Several models of success exist, most of which have been focusing their study on how students achieve their academic potential (Wood \& Breyer, 2017). In previous studies, "success" is often measured in terms of academic performance or persistence in retention of students until graduation (Naylor, 2017). It is evident that the success of the student can be linked to the retention of the student throughout the course of study. According to Allen and Nichols (2017), retention of students is defined as students in a certain year who graduate and continue studying at the same institution the following year. It is expected that the low retention rates of students will affect the institutions of study in various aspects including affecting the sustainability of engineering programs at the university level.

\section{B. Motivation}

Many factors are critical to a student's success in higher education and motivation is one of those key factors. Schneider and Preckel (2017), and Broek et al., (2017) proved that one of the main reasons for high dropout rates in higher education is lack of motivation. Meens (2018), also said that motivation is one of the important variable predicting study success and retention in higher education. Therefore, students that are not motivated have shown the least desirable learning behaviors and academic performance. Motivation is needed as it motivates students to create interest, guarantee and give direction to achieve expected learning goals (Chen, Masek, \& Amiruddin, 2014).

The word motivation is derived from the Latin verb movere, which means to move. Motivation is then concerned with our movements, or actions, and what determines them (Beck \& Jessup, 2004). Motivation can be classified into two parts: intrinsic and extrinsic motivation (Cerasoli, Nicklin, \& Ford, 2014; Pinder, 2011; Ryan \& Deci, 2000) guiding the direction and diligence of one's behavioral performance.

In this study, the researcher will only focus on the extrinsic motivation factor that is seen to influence students in learning. According to Ryan dan Deci (2000) extrinsic motivation differs from intrinsic motivation, which refers to doing an activity solely to enjoy the activity itself, rather than to achieve the value of the activity. This type of motivation perceives the external factors outside the individual as the prime mover in one's action. This study examines how a certain factors externally affect engineering students' retention in the engineering program and success in terms of a high CGPA. According to Paimin (2014), there are two components in extrinsic motivation that externally influence student success which are people (friends, family and lecturer) and program (engineering profession, industrial training, facilities, real world application, program/activities, industrial visit and course requirement).

\section{Different types of extrinsic motivation}

Theories of motivation are created to help us explain, predict and influence behavior. One important approach to motivation has been to distinguish between intrinsic and extrinsic motivation (Deci \& Ryan, 1985). According to Ryan and Deci (2000), contemporary theories on motivation assume that people engage in activities because they believe the behaviors will lead to desired goals or outcomes.

Extrinsic motivation refers to individual performance in certain activities to maintain some tangible result. According to Self Determination Theory (SDT), extrinsic motivation can be very different in its relative autonomy. Internalisation and integration are an important concept in describing extrinsic motivation. According to Ryan and Deci (2000a), internalisation is a process of value-taking or regulation, and integration is the process by which a person completely changes the rules themselves which involve their feelings. Internalisation is also known as a natural process in which individuals try to change social practices, values or regulations into personal-supported values. Regulations refers to what governs or determines behavior, or in other words, what causes behavior.

When the internalisation process works optimally, an individual will automatically receive it as its own regulation. In SDT internalisation is seen as a continuum. The continuum refers to an entire description, continuous structure or series that should not be separated. It explains how everyone's motivation differs from amotivation to selfregulated motivation. How the autonomy of an individual act is dependent on the extent of regulatory behavior that is extrinsic motivation. According to Deci and Ryan (2000; 2000a; 2002), Self Determination Theory has identified four types of extrinsic motivation: external regulation, introjected regulation, identified regulation and integrated regulation.

External regulation is the weakest type of extrinsic motivation. This is the classic case of extrinsic motivation in which man's behavior is controlled externally to gain material rewards; or to avoid threats and punishments. According to Waege (2017), an example of students' behavior is that externally-motivated is when they study only to get good grades in return. Another type of extrinsic motivation is introjected regulation. This kind of regulation is partially internalised by the individual but not accepted as one's own. Intorjected regulation is the sense of pressure to avoid guilt and shame and to attain a feeling of pride or worth. According to Saeed and Zyngier (2012), introjected regulation is a task done for ego enhancement. A student is regulated by introjection if he gets into class on time to avoid being seen as a bad person. 
Identified regulation is a more autonomous or selfregulated type of extrinsic motivation. If a regulation or goal is personally valued by the individual, and is consciously accepted as one's own goal, the regulation is identified. According to SDT, identified regulation has an internally perceived locus of causality (Deci \& Ryan, 2000; Ryan \& Deci, 2000a, 2002). When students work hard to get good results because they believe it is important for their future and to get job opportunities, this motivation is adopted voluntarily. The regulation for their behavior is identified because they are doing it for personal reasons. Integrated regulation is the most autonomous type of extrinsic motivation. According to Ryan and Deci (2002), integrated regulation involves both identifying the importance of a certain behavior, as well as a harmony between the behavior and the individuals' own values, goals, and needs that are already part of one's self. In short, identified regulation is the volition to attain perceived important outcomes, rather than because the activity is inherently interesting or enjoyable.

\section{METHODOLOGY}

By using relativist ontology and constructivist epistemology, the current study revealed perceptions of final year engineering students who enrolled in MTUN universities on study success and importance of extrinsic motivation. Semi-structured interviews were conducted and recorded with participants' consent. The interviews took place individually and were approximately one hour in length. After the interview transcription, thematic analysis was undertaken to identify common themes using the ATLAS.ti. According to Saeed and Zyngier (2012), perception is what one considers to be true on what directs his or her actions, thoughts and feelings. Therefore, in this study we explored the thoughts and feelings of students on how they managed to maintain their motivation to stay in the engineering study program and achieve high GPA.

To understand a case or phenomenon qualitatively, the researchers chose qualified participants via purposive sampling (Silverman, 2013; Creswell, 2013; Merriam, 2009). This sampling method aimed at finding a group of subjects with the specific characteristics to abide by the underlined research purposes. The purposive sampling selection of participants in this study was made by using referral and chain referral techniques.

All the participants were final year engineering students obtaining a CGPA of at least 3.60 and above. Altogether they were a total of 24 students who participated in this study. They specialised in three main fields of engineering (Civil Engineering, Electrical Engineering and Mechanical Engineering) from four technical universities (UTHM, UTeM, UMP and UniMAP). According to Bagheri and Saadati (2015), data from participants chosen via purposive sampling ensures richness and completeness of data for the phenomena under study. Ethical considerations were observed and a full consent was obtained from the Universities, the faculties and the participants themselves before we collected the data.

\section{RESULTS AND FINDINGS}

The results of this study show that there are three main factors of extrinsic motivation. These factors were found to have affected students' motivation to stay in the field up to their final year of studies, while maintaining excellent results reflected in the Grade Point Averages (GPASs).

The results show that the extrinsic factors can be grouped into first (i) people (family, peers, lecturers and community); second, (ii) the program (engineering profession, industrial training, facilities, real world application, program/activities, industrial visit \& course requirement); and lastly (iii) the incentives (scholarship loan and rewards). These data had a high saturation level. The findings from in-depth semi-structured interviews showed merging and overlapping information. This implied that the data were already exhaustive and enough for answering the research question. Each factors will be discussed next in the following subsections.

\section{A. The People factor}

A strong motive in achieving something driven by continuous support, praise, assistance received from significant others in one's life is shown as one of the factors of our participants' extrinsic motivation. As with other motivational factors, the urge to get support from the beloved ones explained the behavior of seeking good GPAs or avoid failure. These people were mainly their family members, peers, university lecturers and communities.

According to Ryan and Deci (2000), extrinsic motivation represents behaviours initiated to attain a desired external consequence or to avoid punishment. For example, a student continue with their studies in certain bachelor's program to avoid negative consequences by trying hard to get good grades and to be praised by their parents and family.

The family, namely the parents was found to be the most influential external factors. All the participant interviewed said they tried to get the best results to please their parents and family members. This is unsurprising because parents and families are the main drivers for achieving success among students on average, across filed of specialisation and regardless to task difficulty. For example, these participants said :

I want to maintain good result for my family, I don't want my mother and my father to be sad or angry and I don't want them to be worried about me. I tried very hard because when I get good results they would feel proud of me. (Participant 24)

This shows that family is the key drivers for their rate of retention in their study, and also success as measured through good exam results. Twenty one (21) out of whole participants (24 altogether) said they would like to repay all the sacrifices being made by their family to support their studies.

I did my best for my family because it was my motivation because they had sent me away from home and financially supported and provided a car for my convenience. If I did not study so hard I would feel guilty. So I appreciate my 
family by showing them good result. (Participant 4)

The results of the study show that every time student get good results, parents and families will gave them a big compliments as a response to them. From that point on, the compliments received became an encouragement to the students to continue to strive hard. According to Shaharuddin et. al, (2017), compliments on student achievements are the main drivers for students to work harder to achieve excellent results. 16 Participants stated that the praises and acknowledgements given by their families had really motivated them to do better. For example

Everytime I told my parent about my result they congrates me and praise me. It feels like (the praises) are thing I worked hard for. I want to work harder for the next semester because I want to get more from my family. (Participant 11)

A part from that, we also include being an example or model in the family by having excellent results as a kind of implicit acknowledgement from the family members. A total of 10 participants said they were trying to maintain a good GPA to be good examples in the family; or as a reaction such feeling of pressure to compete with other family members. For example:

I think I have to do something because I need to break the family tradition of not pursuing studies in higher education institutions. My cousins quitted early, they were SPM holder only. I am the only one who stepped into the university life and enrolled in a government university. No one in my family went for any university except me. They just aimed for SPM, and some of them went for certificates only. So there's no one who made it to the undergraduate degree. So among all my families I am the only one who studying degree in engineering. I must get good result to show them I am the best. (Participant 2)

Aside from family recognition, the results show that students who come from supportive families were more motivated to achieve good results. According to Joyce et. al, (2019) support from family member is important in shaping students' determination to succeed in their studies. Based on the data, support can take the form of advices; or enthusiasm to help; or openness in sharing all the problems faced by the students. These were found to reduce students' burden. 23 participants agreed upon the relentless support provided by their families to motivate them to survive until now (final semester). Some of the interview excerpts are as follows:

If I told my family about my hardship to score in the exam and feel pressure, my parents would advise me like "no need to be too stressed, just do the best and if you cannot get high marks it does not matter." Because my mother said like that it makes me more motivated to prove I can get good results. (Participant 16)

Another aspect of the roles of family in boosting students' motivation extrinsically is the high expectations from the family for the students to change the future of the whole family. According to Meens (2018), someone is motivated by extrinsic motivation when he does something because somebody else is expecting him to do that. This suggests that students retained in the degree programs and earned high GPAs to fulfill family's expectations. Half of the participants expressed their concerns over all the investments and hardships made by their families to give them proper education. Their families were hoping that they pursue their studies and excel by getting good results for a brighter future, so that they can help their families later when they can contribute back to the family.

Once, I feel like I have had enough with my study and also frustrated and I don't want to study anymore. I just sustain until now because my parents forced me and they said "You have to study because we don't come from a rich family". My mom is approaching her 60s but till now she's working and she said she have suffered a lot of pain. However, despite of her pain when I told her that I get good results she was so happy and she said "I have struggled a lot but you made me happy". I studied hard to get good results for the sake of my parents. (Participant 2).

The students' friends or peers is the second aspect of extrinsic motivation that comes from the people factor. They are the second most important group in one's life after the family. The results showed that peers could influence students' motivation. In this study the roles of peers refers to the roles that the participants' friends have played in ensuring participants' retention in their engineering studies until final year. Their peers were also found to have supported to achieve excellent result reflected in high GPAs.

Based on the analysis of the interview 22 participants stated that study groups have a benefitted them in many way. According to Zepke (2018), studying with peers is one type of practical learning approach that affects students' success. This approach enhances student understanding and encourages students to learn early and deeper about something. Among the responses are:

Peers can increase my interest while completing projects as the course requirement and learning together. I could take advantage from friends who's good at designing, and in exchange, my friends take the advantage of my skills in electronics. With that we will share our knowledge and skills and thus engineering interests will also increase. I will also try to master a subject so that I can share with other friends in the future (Participant 10).

During the course of the study, students faced various challenges because learning is a long process. The participants opined that their peers happened to be the key drivers for keeping up with all hardships starting from their first year of study. This shows that peers are extrinsic impetus for student to study. Zepke (2018) states that positive relationships with peers are important predictors for retention and better grades since the start of one's study phase. The peer-to-peer relationships could also involve bigger circles of student from different classes, faculties or even universities. The circle of the peers facilitate students to solve common learning problems and gain additional reference sources.

If I have any problem I will go and meet the senior studnets who scored well in certain subject. I know one. He's a famous student because he always get higher grades in his faculty. So I asked him to teach me the difficult subjects that I could not understand easily and he helped me. (Participant 13) 
In addition, positive words given by the peers directly and indirectly affects these participant. The students got good advices and supportive comments from their peers from time to time. For example, at one time a student can encouraged his/her friends to review the lessons. Other times the student could help reduce all the stress by sharing problems with study partner and getting advices. Participants also regarded their peers as a replacement for the families in certain way because at the university level students spent less time with family as compared to the time spent with friends. 11 participants said they received peer support in terms of advices and motivational words.

Whenever I feel very upset and very depressed my friends understand my feelings and always support me. She always said "No you can, you are the only one who knows your real capability and I know you can do it so you have to go on". I really can't, but she said "No you cannot do like this, go to Youtube where you can learn a lot". I think because of her I got motivated and in the end I managed to get A. (Participant 11)

Good examples portrayed by senior students who have joined the work forced could be regarded as people factor of extrinsic motivation as well. The students witnessed those among them who have succeeded in becoming engineers and that made the students strived really hard to be like them. 10 participants showed their eager to become engineers after seeing a friends who has worked as a professional engineer. So they maintained good result throughout their years at their universities for a greater chance to get desirable careers like what happened to those seniors.

My senior acquaintances who have worked share their experiences as successful engineers, and this make me really excited to be like them. I want to be an engineer someday and then I can tell my experiences to those seniors, then I will show that I can also make it. (Participant10)

Seven participants said that they work hard every semester because they compete with each other. This shows that peers played a good role in the sense that it promotes healthy-competition among them. According to Pauw and Petegem (2017), students working on the basis of extrinsic motivation are students who seek to obtain recognition from others. The reality explains how students strive to be the best students to be recognized and known among colleagues in the university.

Actually sometimes I see my friends like my competitors. I want to get better result than them or equal to what they get. I don't really like my results to be far behind them so that motivates me to do better. (Participant 24)

Finally, our data showed that lecturers were equally important as the third aspect of the 'people factor' that fall under extrinsic motivation. Their lecturers were responsible for providing knowledge and helping the students, support by data from other similar studies like (Tharek, 2011). 23 participants agreed that helpful lecturers motivated students to success.

If I did not understand something during the class I would ask question to the lecturer. Lecturers at this faculty are kind, they will come close to the students and ensure that all students understand what is taught. If there are students who still do not understand, they will repeat the topic until all the students understand. (Participant 23)

Lecturers that motivate the students also provided a complete and adequate reference sources for them. Access to good and useful study resources will maintain students' interests in learning. 16 participants said their lecturers provided a complete reference source and the exam tips were given so as to explicitly guide them to score in their exam.

I focused on the notes given by lecturers only. This is because they helped in the exam. Lecturers will recommend related book for each subject and if student spend adequate time to read, it will facilitate students' understanding. (Participant 8)

In addition, lecturers with former working experience as engineers were also seen to affect students' perception about their bright future. Half the participants showed an excited reaction when attending classes taught by lecturers who experienced working as engineers because these lecturer would explain pragmatically on aspect related to engineering field of work as a reality; not merely theoretically. Therefore, lecturers' previous experience as engineers indirectly affected students' interest in the subject being taught and at the same time triggered students to make it a point that they must become engineers someday.

Sometimes the experience told by a lecturer increase my interest to the engineering subjects I learned because most of our lecturers are former engineers who used to work with the industry. When they told me about the experiences they had gone through, I would be thrilled to know more. (Participant 14)

Furthermore, students were seen to work hard to maintain a good result to get compliments from the lecturers. According Waege (2017), students who are extrinsically motivated engage in tasks to obtain extrinsic rewards, such as praise and positive feedbacks from their lecturers. Half of the participants mentioned that the compliments from lecturers motivated them to do better. This made them felt special and that the lecturers realized his presence in class. There were times, when lecturers announced names of student who scored the highest marks in the class.

I feel great if my lecturer knows me because I am the best student. When I got 3.94 and 3.88 for my GPAs my lecturers praise me because I was the student who got the highest mark for the subjects they taught. (Participant 22).

Finally, the participants also highlighted that they sought for societal acceptance and respect among the community members. Being an active member of society to gain respect and acknowledgements from them, again, is one prove of extrinsic motivation. This was clearly explained by the participants as follows:

I want to score good grade because in society everyone think of high pointers as intelligent individuals. People have positive expectation towards high pointers that they are competent and all-rounders. Society includes everyone on top of my family, my friends. Actually if one achieve high grades, the person will achieve the rest. So this is my main 
target. Also, when I achieve high CGPA everyone will praise and look up to me (Participant 15).

Empathy towards community is another facet of the extrinsic motivation driven by the society. Participants expressed some concerns about problems faced by the community due to lack of technology knowledge. This called for young engineers to transform and help their communities for betterment of the society at large through the field of engineering. Ashar (2016), states that the engineering field is one of the determinants of quality in modern lifestyle where every object around us, alive or dead, is closely linked to engineering. 17 out of our participants asserted that they wanted to gain as much knowledge as possible to contribute to the society and helps solve engineering problems that people may encounter.

In my hometown area often have trouble maintaining their electricity supply. I feel sorry and I hope with the knowledge that I learned at my university, I can help the community. For example, with the wiring certificates that I have, I can help my hometown by making a new wiring system because they cannot afford to pay expensive contractors (Participant 9

\section{B. $\quad$ The Program Factor}

A university program is all requirements that students should meet with the conditions outlined by the university to obtain a Bachelor's Degree. The analysis also yields rich data on the factors of extrinsic motivation related to the quality of the academic program structures given by education providers. The current study shows that quality study programs can motivate students extrinsically to retain until the course completion and also achieve high GPA. Bachelor in engineering is normally a full-time, four-year program that comprises of engineering apprenticeship attachments, industrial training, PBL (problem-based learning) where students are exposed engineering problem solving in the real situation among others. Extra-curricular programs and activities embedded in the program, industrial visits, are also part of education program. On top of these, university facilities that accelerate the running of all course requirements were also deemed important as prime movers of success.

Program outcomes refer to what students are expected to know and achieve and what they can implement upon graduation. This relates to the skills, knowledge, and behavior gained by students through the engineering program (Engineering Accreditation Council, 2017). Among the expected program outcomes are engineering knowledge demonstrated through mastery in the use of mathematical knowledge, science, engineering principles and so on to solve complex engineering problems.

Completing all the special requirements in the program is one of the preconditions for students in order to graduate. Required of course requirements provide direct insistence to students. For example, students need to collect at least 135 credits where 90 credits must be the engineering subjects spreaded over the four years of their study. Therefore, students are motivated to plan how to collect those credits. To do that, they surely would have to retain until they fulfil all the requirements across the duration of their study. 15 participants said that they were urged to comply with the course requirements that they set many strategies to achieve good results for their examination.

Submitting assignments on time and scoring high marks in quizzes and tests are important because they accumulate and affect my GPA. Therefore, to keep me notified I will make memos in my phone with details such as due dates and which work to be completed at a particular time. Quizzes and test dates are not going to be missed so that I will make sure I do enough preparation so that I can score high marks. (Participant 13)

The results of the study show that industrial trainings they went through gave the biggest impact on students' motivation. The EAC (Engineering Accreditation Council) has underlined that before any engineering program is recognised, the program should allocate eight weeks especially for industrial training at the minimum. This condition must be followed for the university students to be eligible to obtain a degree and as such enter the job market. 20 participants indicated that during the industrial training, students were given with the opportunity to learn a variety of knowledge and skills throughout the training period. For example;

In my classroom I learned a lot of theories but during my industrial training I put that theories into practice. I had the opportunity to learn a whole range of knowledge and do it practically. I have learned new skills such as how to properly plug in the cables and break supplies. I learned from various departments and gained a lot of knowledge from every department (Participant 9).

The knowledge acquired during the industrial training is also seen to have prolonged good effects on student learning of engineering concepts even after the completion of the training period. More than half of the participants said they were more eager to learn because they had encountered real problems and dealt with them during their industrial training. For example:

After going to my industrial training, the subjects taught in the classroom became clearer as I have seen the practice in a real setting. We can relate what we learned during industrial training to the subjects taught in the classroom. It becomes very interesting and it was very helpful for my study (Participant 13).

Industrial training is also seen indirectly influencing the motivation of 20 Participants to engage in engineering professions. Where during their industrial training periods they are given the opportunity to do real work as engineers and increase their interest to become an engineer. For example:

At first I was confused about the engineering field and often questioned how the scope of work would come and I would fit in which part. After undergoing industrial training I better understand how work as an engineer and I am more interested in the field I am involved in (Participant 3).

Apart from attending industrial training as educational requirements in the study program, 10 participants said that industrial visits from university to the industry, or vice versa, would also benefit their learning as they can get more 
exposures to the real engineering solutions that is of the industry's main business. For example:

When engineers from the industry come to the university to give a talk, I am really excited to listen to them especially on their experience as engineers. They would talk about what they had created and what had changed for the community as the outcome of their creativity. The knowledge I acquired during the sharing sessions has helped me to improve a great deal of my idea in the written assignments or project reports my lecturers instructed us to complete (Participant 12).

It also explains the real situation is one of the students' interest in learning about something. A student is more motivated to learn after saw the real situation and it increases the understanding of something. 18 participants state that the real situation related to what is being taught in the classroom makes it easy for them to score in the exam. For example:

The real situation helps a lot especially in engineering has a lot of resources that we can see examples like YouTube. I watch YouTube a lot if I do not understand something and it's a lot more helpful than simply reading a book because through see the real situation I will understand more about what I learned in the classroom. (Participant 6)

Furthermore, 20 Participants also pointed out that maintaining a good pointer is due to aspiration to become an engineer. They also think that getting a high GPA makes it easier for them to get jobs later. For example:

Furthermore, the competition is very high because nowadays many engineering graduates have the awareness to pursue studies to masters and $\mathrm{PhD}$ levels, making a bachelor's degrees considered to be just a piece of paper. I want to get a high GPA because at least I can increase my chances more than anyone else. I think by getting a high GPA I would get a bigger chance to get the job I want. For example if there are 10 resumes but my pointer is higher maybe I will be selected as a candidate for interview. (Participant 16)

It is acknowledged that apart from knowledge, education is bound to provide relevant skills to students in a complete study program. Universities around the world provide selfhelp and community programs to provide all-rounders who also excel with A high GPAs. Qualities such as leadership, communication skills and cooperativeness are the values employers are looking for in prospect employees. 17 participants emphasized the importance of extra-curricular activities to hone their soft skills such as time management, responsible behavior, and also communication and leadership skills. They also stated that these skills would have a good impact on future job opportunities. For example:

In my opinion, the activities that I have organised shaped my personality. This is because personality is not formed only through reading books, we must start outreaching to people. Hence by engaging myself with a lot of activities I can be sure to communicate with others regardless of rank and age. I think my current personality will make it easier for me to cope with any future challenges at the work place. (Participant 21)

Extra-curricular activities motivated these participants to excel and sustain in their studies by getting involved and be validated with prizes, honors and certificates that may attract potential employers during job interviews. For example:

I think what is important during the university life is to keep myself busy through joining a lot of programs and activities because from the program I can get the certificates, and extra knowledge, which are useful in the future. I can get many certificates and attach them in my resume to increase the chance to get job offers (Participant 11)

In addition, 11 participants stated that their involvement in extra-curricular activities would also initiate collaborations with senior college mates or people other universities. The good relationships have a good impact on learning through sharing of study notes, additional references from other students. It indirectly affects students' motivation to learn because every positive thing that facilitates learning will increase student motivation. They said:

For me the advantages of participating in programs and activities are that I have the opportunity to get to know many seniors and I can ask for notes and ask them about the difficult topics that I do not understand. If I did not participate in the program or activity I would not know the seniors from other batches and senior from other faculty from whom I can get useful advices. This is important for us to remain until the end of our studies. (Participant 22)

Complete and pleasant school facilities were also related to participants' motivation based on the interview data. 18 participants stated that a conducive environment provided by the university will support the learning process of students in a significant way. The participants also stated that their university and residential colleges have also provided complete facilities to ensure positive atmosphere on-campus and to boost their motivation to study.

Real machines will increase my interest in the engineering subjects being studied. If the facilities are insufficient I think students will not be clear about a certain machine if they rely solely on what is shown in the textbooks (Participant 10)

In addition, the complete facilities provided in the library also affect students' performance. This is because with perfect libraries it is easier for students in getting access to learning resources. Facilities also include a comfortable space for reading off-line in the libraries.

I really enjoy my university and its environment, including the facilities provided in the library. I really like this library because there are many comfortable lecture rooms and rest rooms to accommodate students as well as the public at a time. My friends and I make revisions and preparations for our lectures and assignments together in this library since it is a lot easier to obtain the books for our reference here. I would prefer to study at the library because it is more comfortable and quieter rather than at home. (Participant 7)

The results show that all the participants interviewed use the internet as a primary information-seeking method. It is found that students become more motivated when they have 
seen things for themselves. To learn something visually in online videos increases students' understanding of something. 18 Participants had stated that watching videos related to the topics being taught in the classroom helps with memory and this is an important factor of success in their final examination. For example:

People learn a great deal of information from seeing things demonstrated to them in step-wise fashion. There is a lot of audio-visual resources that help support my study in engineering including the 'YouTube' videos. I watch YouTube videos a lot if I do not understand something and it's a lot more helpful than simply reading a book because I will understand more about what I have learned in the classroom. (Participant 6)

Specifically, 17 participants stated that the internet provides a variety of sources of reference. Speedy access to first-hand information is important when one is looking for solutions in academic activities. Internet videos and websites can ease the whole process and this affect students' motivation to learn. For example:

I just follow the Youtube channel for certain lectures. They teach very well in the Youtube. They teach the same subjects and chapters that are being taught in the class we attended. They supplement the videos with revision question so that is the most useful thing that I have found. I think fully online classroom will be an ideal course structure because I can always repeat the videos whenever I want. (Participant 2)

Furthermore, half of the participants pointed out that easy to access to the Wifi with high speed helped a lot in the learning process. These are their statements:

I spent a lot of time searching for a source or reference on the internet. I am very satisfied with the wifi provided in universities and colleges (Participant 15).

\section{The Incentives Factor}

Extrinsic motivation is also manifested through the incentive factors. Incentive refers to the availability of scholarships, loans and rewards that will be given if the student achieves excellent results. Reeve and Cheon (2016), controlled motivation is the motivation to earn rewards through controlled actions. It falls under extrinsic motivation. Controlled motivation refers to how one controls each of his behaviors to achieve what they dream of. the results showed that 18 participants made loans through the Perbadanan Tabung Pendidikan Tinggi Nasional (PTPTN). These borrowers said they were trying to get a good results because the PTPTN will waive excellent students from the loan repayment. PTPTN is a Malaysian corporation that provides alternatives for students having difficulty paying for their tuition fees in public and private higher learning institutions in Malaysia.

Among the two main requirements outlined by PTPTN for eligible students are the students who are awarded the First Class Bachelor's Degree and the students who graduated within the specified period of study program. All Participants who make educational loan agreements through PTPTN claim that they were trying to sustain and get the high GPA so that they would not have to repay the amount of loan that has been received. For Example:
I make education loans through PTPTN, I need to maintain a high GPA starting from the first semester because I need to reach First-class results for payment exclusions. (Participant 7)

Out of the 24 participants, only six participants did not make loans from the PTPTN. Three participants were sponsored by various sources including scholarships from state governments and large companies. The three participants said they needed to maintain a high GPA for the continuation of the scholarship. Otherwise, the sponsors will be stop ceased. This demonstrates how insistence from the sponsors motivated these students continuously so that students were always working hard in order to make sure that they graduate with good results. Efforts made to mobilise individuals towards one or more specific goals and to ensure achieving rewards or gifts is an extrinsic motivation.

I was financed by state scholarship. I continue to work hard until the end of the year and always strive to get a good GPA because it is the requirement by my sponsor if I were to continue the scholarships till my graduation. (Participant 9)

Award-giving ceremonies affect students' motivation in that their universities hold the dean's award ceremony for students who earn a 3.50 GPA. It made them really excited to strive and achieve high GPAs to be invited to the event. University's affirmation can increase the student's motivation to seek the reward they expected to get by fulfilling the conditions. 11 participants stated they tried to be listed in the dean's list each semester because they wanted to obtain a dean's certificate and were invited to a dean's ceremony. For example:

Faculty's award ceremony is very fun because the faculty like celebrating their students. This lively dean's award ceremony makes the students get recognized by the deans. I feel proud and happy because at the end of the year I still managed to get into the dean's list while my friends cannot maintain. (Participant 12)

Participant also strives to get a high GPA so that their success in the graduation certificate will be written with "First Class Honours Degree Holder". This would make for a better job opportunity because the certificate holders get a higher GPA compared to others. For example :

I always imagine someday I will wear a convocation robe on the stage and my name is written on my certificate as a holder of a first-class bachelor's degree. I try to reach my dream. My main goal is to get a brilliant award as one of the weapons to impress the employer, so that they would not be reluctant to choose me as a potential employee (Participant 6)

Lastly, the results show that there are participants saying they are trying to sustain and gain a high GPA for better climb in higher qualification in the field of engineering, so they will someday get an 'IR' title. The title is considered as a targeted reward because indirectly they loved to be praised by the people and at the same time these titles generate 
lucrative income. For example :

My main goal is to get IR tittle, I want to be in engineering profession because engineer can get a lot of salary. I hope to be an engineer and I dream to get the IR tittle and get a lot of money (Participant 4)

In addition, participants said that the high pay received by professional engineers sparked their interest. This caused them to double their efforts in their study. According to Meens (2018), extrinsic motivation also include goals and that is oriented by the behaviors to earn financial rewards. Here is what the participants said about how a good pay motivated them:

I studied hard to get a good GPA for a good job to earn a lot of salary. My dream is to become an engineer because I know by becoming as engineers I can get a high salary. (Participant 19)

\section{CONCLUSION}

The overall results of this study showed that students who were highly motivated tended to achieve academic success in higher education. This study has brought three main factors as potential variables that motivate students in higher education. These factors are people, program and incentives. They each have some motivational impacts on students learning as shown in the presented data. The common theme running through the three factors is their catalytic nature in motivating student to get what they aim for such as work opportunity, salary, praise from others and reward. According to Karadag (2017), behaviors derived from external sources, such as rewards, penalties, and social support, is the behavior associated with the outcome of individual actions. Hence, the knowledge and understanding of these factors have informed us a lot on the tendency of performing well in higher education by enforcing the factors in the future. However more studies are needed to examine into how these extrinsic motivation can influence intrinsic motivation of the students to ensure their success in studying engineering. This study has been able to establish the fact that external factors do influence and sustain the students' will power in higher education institutions to achieve success.

Overall, this paper contributes to understanding of the external factors of the motivation to study in higher education. This understanding, especially by both students and administrators of higher education has the potential of enhancing the success of students pursuing graduate studies.

\section{ACKNOWLEDGEMENTS}

The researchers thank the Ministry of Higher Education Malaysia for supporting this research and the related publications through FRGS 1605 grant. The author also like to thanks engineering students at MTUN universities for their cooperation in this research.

\section{REFERENCES}

1. Agensi Kelayakan Malaysia. (2011). Standard program: Kejuruteraan dan teknologi kejuruteraan. Agensi Kelayakan Malaysia, Selangor.

2. Ashar, M. K. (2016). Negara perlu lebih ramai jurutera menjelang 2020. Retrieved February 2, 2018, from http://www.eng.usm.my/index.php/ms/more-articles/226negara-perlu-lebih-ramai-jurutera-menjelang-2020

3. Bagheri, A., \& Saadati, M. (2015). Exploring the Effectiveness of Chain Referral Methods in Sampling Hidden Populations. Indian Journal of Science and Technology.

4. Beck, R., \& Jessup, R. (2004). The Multidimensional Nature of Quest Motivation. Journal of Psychology and Teology.

5. Broek, A. V. D., Wartenbergh, F., Bendig-Jacobs, J., Robert Tholen, R., Duysak, S., \& Nooij, J. (2017). Monitor beleidsmaatregelen 2016-2017. Onderzoek in opdracht van het Ministerie van Onderwijs, Cultuur en Wetenschap.

6. Cerasoli, C. P., Nicklin, J. M., \& Ford, M. T. (2014). Intrinsic Motivation and Extrinsic Incentives Jointly Predict Performance?: A 40-Year Meta-Analysis. In Psycological Bulletin. Advance online publication. http://doi.org/10.1037/a0035661

7. Chen, U. R., Masek, A., \& Amiruddin, M. H. (2014). Kajian gaya pembelajaran dan motivasi terhadap pencapaian pelajar diploma kejuruteraan di politeknik. In CiE-TVET 2014.

8. Creswell, J. W. (2013). Qualitative inquiry \& research design (Third Edition). Thousand Oaks, CA: Sage.

9. Deci, E., \& Ryan, R. (1985). The general causality orientations scale: Self-determination in personality. Journal of Research in Personality, 19(2), 109-134.

10. Joyce L. Epstein, Mavis G. Sanders, Steven B. Sheldon, Beth S. Simon, Karen Clark Salinas, Natalie Rodriguez Jansorn, Frances L. Van Voorhis, Cecelia S. Martin, Brenda G. Thomas, Marsha D. Greenfeld, Darcy J. Hutchins, K. J. W. (2019). School, Family, and Community Partnerships: Your Handbook for Action.

11. Karadag, E. (2017). The Factors Effecting Student Achievement. Springer International Publishing.

12. Kementerian Pengajian Tinggi Malaysia. (2016). Perangkaan Pendidikan Negara?: Kementerian Pendidikan Tinggi. Retrieved August 10, 2018, from https://www.mohe.gov.my/muatturun/awam/statistik/2016-statistik/402-bab-2-universitiawam-2

13. Lashari, T. A. (2015). The effect of integrated affectivecognitive teaching and learning approach on student's learning in engineering education. Universiti Tun Hussein Onn Malaysia: Tesis Ph:D.

14. Merriam, S. B. (2009). Qualitative research: A guide to design and implementation (Vol. 53). John Willey and Sons, http://doi.org/10.1017/CBO9781107415324.004

15. Moulod, S., Chua, Y. P., Ahmad, H., Leong, M. W., \& Alias, S. (2016). Kecerdasan Emosi dan Hubungannya Dengan Efikasi Kendiri Guru Sekolah Menengah. Jurnal Kepimpinan Pendidikan.

16. Paimin, A. N. (2014). The success factors of engineering students: Learning strategies, interests and intentions.

17. Pauw, J. B., \& Petegem, P. Van. (2017). Because my friends insist or because it makes sense? Adolescents motivation towards the environment. Education for Sustainable Development \& Environmental Education.

18. Pinder, W. C. C. (2011). Work motivation in organizational behavior (2nd ed.). New York, NY: Psychology Press.

19. Reeve, J., \& Cheon, S. H. (2016). Teachers become more autonomy supportive after they believe it is easy to do. Psychology of Sport and Exercise. 
20. Ryan, R., \& Deci, E. (2000). Self-Determination Theory and the Facilitation of Intrinsic Motivation, Social Development, and Well-Being. American Psychologist, 55(1), 68-78.

21. Ryan, R., \& Deci, E. (2002). Handbook of selfdetermination research: Overview of self-determination theory: An organismic-dialectical perspective. Rochester, NY, US: University of Rochester Press.

22. Ryan, R. M., \& Deci, E. L. (2000). Intrinsic and Extrinsic Motivations: Classic Definitions and New Directions. Contemporary Educational Psychology, 25(1), 54-67. http://doi.org/10.1006/ceps.1999.1020

23. Saeed, S., \& Zyngier, D. (2012). How Motivation Influences Student Engagement: A Qualitative Case Study. Ournal of Education and Learning, 1, 252-267.

24. Schneider, M., \& Preckel, F. (2017). Variables Associated With Achievement in Higher Education: A Systematic Review of Meta-Analyses. Psychological Bulletin.

25. Shaharuddin, H. N., Azizan, K. F. ku, Ismail, W., Rosnan, F.-N. R., \& Gordani, N. (2017). PENGAJARAN DAN PEMBELAJARAN BAHASA ARAB DALAM. In Persidangan Antarabangsa Sains Sosial dan Kemanusiaan.

26. Silverman, D. (2013). Doing qualitative research q practical handbook (Fourth Edition). SAGE Publication, Inc.

27. Tharek, M. (2011). Tekanan kerja dan kepuasan kerja pensyarah Universiti Teknologi Malaysia. Universiti Teknologi Malaysia: Tesis Sarjana.

28. Waege, K. (2017). Motivation For Learning Mathematics in Terms of Needs and Goals. In Proceedings of CERME 6. Programme for Teacher Education, Norwegian University of Science and Technology, Trondheim.

29. Zepke, N. (2018). Learning with peers , active citizenship and student engagement in Enabling Education, 9(1), 6173. http://doi.org/10.5204/ssj.v9i1.433

\section{AUTHORS PROFILE}

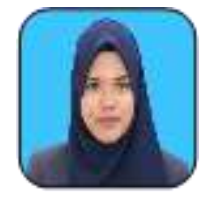

Nur Hidayah Mohamed Yunus received degree in Bachelor of Vocational Education (Electric \& Eelectronic) with Honours from Universiti Tun Hussien Onn Malaysia and is currently a postgraduate student (masters) at Universiti Tun Hussien Onn Malaysia and is currently a graduate intern at Faculty of Technical and Vocational Education (FTVE).

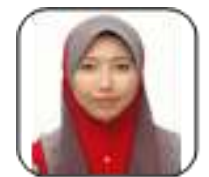

Aini Nazura Paimin is a lecturer at Universit Tun Hussein Onn Malaysia. Her research interests include learning motivation, learning strategies, study interest, conative domain, and engineering education. She actively involved in curriculum development project and is currently teaching mechanical engineering subjects at the Faculty of Technical and Vocational Education. 